\title{
IMPLEMENTASI KEBIJAKAN PENDIDIKAN LINGKUNGAN HIDUP DI SEKOLAH ISLAM TERPADU DALAM KAJIAN LITERATUR
}

\author{
Dedik Dwi Prihatmoko ${ }^{*}$ ) \\ 1)Magister Pendidikan Guru Madrasah Ibtidaiyah \\ FITK UIN Sunan Kalijaga Yogyakarta \\ prihatmokodedik@gmail.com
}

*Penulis koresponden

\begin{tabular}{|l|l|l|}
\hline Diajukan: 22-11-2020 & Diterima: 14-12-2020 & Diterbitkan: 29-12-2020 \\
\hline
\end{tabular}

\begin{abstract}
Every country has different environmental problems that have an impact on the variety of policies and implementation of environmental education (PLH). The development of environmental education is dynamic and attracts attention so that it is always discussed in order to find solutions. Integrated Islamic Schools (SIT) in Indonesia also need to consider it as a major part of their education even though the leveled schools from elementary to secondary level have specificities in the implementation of Islamic character. The offer of literature on environmental education policies is described, although not in its entirety, it is selected in order to obtain an important strategy for its implementation in SIT education. The three policies implementation theori have provided insight into how environmental education should be applied in SIT. The combination strategy with acculturation and habituation is expected to provide a buffering force for character education for all parties involved in integrated education from an integrated Islamic school.
\end{abstract}

Keywords: enviromental education, integrated Islamic schools, policies, implementation

\begin{abstract}
Abstrak: Setiap negara punya permasalahan lingkungan yang tidak sama sehingga berdampak pada variasi kebijakan dan penerapan Pendidikan lingkungan Hidup (PLH). Perkembangannya tergolong dinamis dan menarik perhatian sehingga selalu dibahas guna mendapatkan solusi pemecahan. Sekolah Islam Terpadu (SIT) di Indonesia juga perlu mempertimbangkan sebagai bagian utama dari pendidikannya meski sekolah berjenjang dari tingkat dasar sampai menengah itu memiliki kekhasan pada implementasi karakter Islam. Tawaran literature tentang kebijakan PLH dijabarkan meski tidak secara keseluruhan namun diseleksi guna mendapatkan strategi penting dalam implementasinya dalam pendidikan SIT. Tiga perspektif implementasi kebijakan itu telah memberikan wawasan bagaimana PLH harus diterapkan dalam SIT. Strategi kombinasinya dengan pembudayaan dan pembiasaan diharapkan untuk memberikan kekuatan penyangga terhadap pengembangan karakter
\end{abstract}


bagi semua pihak yang terlibat dalam pendidikan terpadu dari sekolah Islam Terpadu.

Kata kunci: pendidikan lingkungan hidup, Sekolah Islam Terpadu, kebijakan, implementasi

\section{A. Pendahuluan}

Isu lingkungan hidup (LH) telah menjadi perhatian nasional saat ini karena kondisinya yang sangat kritis. Bahkan di kawasan pariwisata yang berskala nasional dengan penataan yang tersistemik, sampah anorganik pengganggu LH masih menjadi permasalahan besar tak berkesudahan. ${ }^{1}$ Hal itu lah yang mendorong upaya penanaman lingkungan hidup tidak dibatasi dalam keluarga dan masyarakat seperti penanaman karakter agama dan kewirausahaan. ${ }^{2}$ Partisipasi aktif dari sekolah juga dipentingkan.

Apa lagi setelah terbit Surat Keputusan Bersama Kementerian Nomor 5 Tahun 2013 tentang pelaksanaan PLH untuk jenjang pendidikan dasar dan menengah melalui program Adiwiyata.3 Program Adiwiyata bertujuan untuk menyikapi masalah lingkungan hidup dengan pengetahuan dan penumbuhan kesadaran siswa maupun masyarakat tentang arti lingkungan bagi keberlangsungan hidup. ${ }^{4}$ Di dalamnya ada upaya pembentukan lingkungan sehat dengan menghindari dampak negatifnya. Integrasinya dalam guna penciptaan kondisi yang baik untuk

${ }^{1}$ Difla Nadjih, Sujarwo Saputro, dan Mukhlas Madani, "Identifikasi Jumlah dan Faktor Timbulan Sampah Di Kawasan Wisata Malioboro ," Nuansa Akademik Jurnal Pembangunan Masyarakat 5, no. 1 (Mei 14, 2020): 35-43.

${ }_{2}$ Arum Yuli Dwi Rahmawati, Muh Nasruddin, dan Imroatun Imroatun, "Peran Sosial Guru Pendidikan Agama Islam Di Wilayah Pesisir Utara Pulau Jawa," Nuansa Akademik Jurnal Pembangunan Masyarakat 5, no. 1 (2020): 1-12; Fattah Setiawan Santoso, "Lingkungan Keluarga Sebagai Awal Pengembangan Kewirausahaan Islam," Nuansa Akademik Jurnal Pembangunan Masyarakat 5, no. 1 (2020): 13-22.

3 Fadila Azmi dan Elfayetti Elfayetti, "Analisis Sikap Peduli Lingkungan Siswa Melalui Program Adiwiyata Di SMA Negeri 1 Medan,” Jurnal Geografi 9, no. 2 (Agustus 8, 2017): 135 .

4 Lilik Nofijantie, "Menanamkan Nilai Karakter Peduli Lingkungan Melalui Pendidikan Lingkungan Hidup Tantangan Bagi FITK," in Prosiding Halaqah Nasional dan Seminar Internasional Pendidikan Islam. (Surabaya: UIN Sunan Ampel, 2015), 8391. 
tempat belajar beserta penyadaran bagi siswa untuk berpartisipasi aktif dalam setiap upaya penyelamatan lingkungan. 5

Sekolah tingkat pendidikan dasar hingga menengah melalui Adiwiyata telah menjadi pengambil peran utama dalam mengkondisikan generasi untuk mulai mengenal, menjaga, dan melestarikan alam sedini mungkin. Di situ, proses mengenali nilai-nilai dan menjabarkan konsep dalam rangka pengembangan keterampilan, sikap yang diperlukan untuk memahami serta menghargai hubungan timbal balik antara manusia, budaya, dan lingkungan biofisiknya bisa terjadi. ${ }^{6}$ Di dalamnya ada proses penanaman dalam aspek afektif, yakni tingkah laku, nilai, dan komitmen yang diperlukan untuk membangun masyarakat yang berkelanjutan (sustainable).7

Sebagai kebijakan yang berprinsip partisipasi berkelanjutan, Adiwiyata ditetapkan dalam empat komponen yaitu: penerbitan kebijakan berwawasan lingkungan, perencanaan kurikulum berbasis lingkungan, penyelenggaraan pembelajaran lingkungan berdasar pada partisipasi, dan penciptaan sarana pendukung yang ramah lingkungan. ${ }^{8}$

Inti dari kebijakan PLH melalui program Adiwiyata di sekolah bahkan bertujuan pada peningkatan kesadaran dan kepedulian manusia terhadap lingkungan hidupnya. 9 Pada Piagam Beograd (Belgrade Charter) telah dijelaskan bahwa tujuan PLH. adalah: Pertama, kesadaran (awareness); memposisikan individu maupun masyarakat untuk memperoleh kesadaran dan kepekaan terhadap lingkungan total maupun masalah-masalah yang menyertainya. Kedua, pengetahuan (knowledge); edukasi individu maupun masyarakat memperoleh pemahaman dasar tentang lingkungan, dan masalah-masalah yang terkait, secara kritis dan humanis, bertanggung jawab dan berperan dalam penanggulangan

5 Theresia Melania Sudarwati, "Implementasi kebijakan pendidikan lingkungan hidup SMAN 11 Semarang menuju Sekolah Adiwiyata" (Universitas Diponegoro Semarang, 2012).

${ }^{6}$ Syukri, Pendidikan Lingkungan,h.39.

7 Wahyudin dan Malik, "Teaching Environmental"

8 Kadorodasih, "Implementasi Pendidikan Lingkungan Hidup Melalui Program Adiwiyata Di SDN Giwangan Yogyakarta," Hanata Widya 6, no. 4 (2017): 43-53.

9 Hamzah Syukri, Pendidikan Lingkungan, Sekelumit Wawasan Pengantar (Bandung: Refika Tama, 2015), h.35. 
masalah tersebut. Ketiga, sikap (attitude) membantu individu maupun masyarakat meraih nilai-nilai sosial, perasaan yang kuat terhadap masalah lingkungan dan motivasi untuk secara aktif berperan dalam perlindungan dan perbaikan lingkungan.

Keempat, keterampilan (skills); memposisikan individu dan masyarakat memperoleh keterampilan dalam pemecahan masalah lingkungan. Kelima, kecakapan evaluasi (evaluation ability); memposisikan individu maupun masyarakat dalam mengevaluasi kegiatan lingkungan dan program pendidikan dalam konteks ekologis, politik, ekonomi, sosial, estetika, dan faktor-faktor pendidikan. Keenam, partisipasi (participation); memposisikan individu maupun masyarakat untuk mengembangkan rasa tanggung jawab dan melihat urgensi masalah-masalah lingkungan serta memastikan timbulnya aksi-aksi yang sesuai bagi pemecahan masalah lingkungan tersebut. ${ }^{10}$ Hal demikian sejajar dengan Undang-undang Perlindungan dan Pengelolaan Lingkungan Hidup (UUPLH) No 32 tahun 2009 Bab X Pasal 65 Ayat (2) menyatakan bahwa setiap orang berhak mendapatkan pendidikan lingkungan hidup, akses informasi, akses partisipasi, dan akses keadilan dalam memenuhi hak atas lingkungan hidup yang baik dan sehat.11

Meski telah diserukan dalam berbagai tingkat kehidupan, namun implementasi PLH di sekolah masih masih banyak kelemahan sehingga perlu perhatian penuh dari banyak pihak. Sungkowo menjelaskan beberapa alasan mengapa hal itu terjadi.12 Pertama, partisipasi masyarakat yang rendah dalam PLH. Kedua, pemahaman terbatas dari pendidik tentang PLH sehingga terabaikan dalam lingkungan formal. Ketiga, materi dan metode pelaksanaan PLH dirasa belum memadai, dan kurang aplikatif. Keempat, sarana dan prasarana dalam pendidikan lingkungan hidup belum mendapat perhatian yang cukup. Kelima, perhatian pemerintah melalui alokasi anggaran belum bisa mendorong

\footnotetext{
${ }^{10}$ Ketut dan Hariyanto, Pendidikan Lingkungan,h.43.

11 Republik Indonesia, Undang-undang Nomor 32 tahun 2009 tentang Perlindungan dan Pengelolaan Lingkungan Hidup, 2009.

12 Sungkowo, Konsep Pendidikan Lingkungan Hidup pada Jalur Pendidikan Dasar dan Menengah (Jakarta: Dikdasmen, 2005).h.47
} 
PLH terselenggara secara maksimal. Keenam, koordinasi lemah antar instansi dengan lembaga pendidikan.

Dewasa ini, implementasi kebijakan PLH ternyata masih didominasi pada pendidikan negeri. ${ }^{13}$ Kajian empiris pada sekolah swasta masih minim bahkan hingga sekolah berciri khas keagamaan tertentu pun sulit ditemukan. Sementara keduanya memiliki hak dan kewajiban yang sejajar dengan pendidikan negeri dalam PLH melalui program Adiwiyata.

Sekolah Islam Terpadu (SIT) di Indonesia juga perlu dipertimbangkan sebagai bagian utama dari PLH. sekolah tingkat dasar menengah itu memiliki kekhasan tersendiri dalam implementasi karakter Islam. ${ }^{14}$ Agama samawi terakhir itu telah menyerukan bahwa pendidikan lingkungan hidup juga bagian penting dalam mengembangkan umatnya. ${ }^{15}$ Sekolah tersebut juga harus menindaklanjuti PLH dalam perspektif Islam pada jenjang anak usia dini, ${ }^{16}$ naik ke pendidikan dasar dan seterusnya

13 Siti Nihlawati, "Substansi Kebijakan Kurikulum Berbasis Lingkungan pada Sekolah Adiwiyata di SMPN 2 Kebomas Gresik,” Didaktika 18, no. 2 (2011): 6-21; Kadorodasih, "Implementasi Pendidikan"; Mohammad Dendy Fathurahman Bahrudin, "Pelaksanaan Program Adiwiyata Dalam Mendukung Pembentukan Karakter Peduli Lingkungan," Gea. Jurnal Pendidikan Geografi 17, no. 1 (2017): 25-37; Erika Donna et al., "Kebijakan Pengintegrasian Pendidikan Lingkungan Hidup Pada Sekolah Adiwiyata (Studi pada SMAN 1 Puncu Kecamatan Puncu Kabupaten Kediri),” Jurnal Administrasi Publik (JAP) 3, no. 12 (2015): 1981-1985; Sudarwati, "Implementasi kebijakan"; Das Braja, "Pendidikan Lingkungan Hidup Sebagai Muatan Lokal Pada Sekolah Adiwiyata di SDN Purwantoro I Kota Malang," n.d.; Khoirul Umam, "PLH di SDN Malang” (UIN MMI Malang, 2018); Ayu Awalia Rahman, I Made Putrawan, dan Mieke Miarsyah, "Hubungan Antara Orientasi Nilai (Value Orientation) dengan Perilaku Pro Lingkungan (Pro Environmental Behavior) Siswa," IJEEM - Indonesian Journal of Environmental Education and Management 5, no. 2 (Maret 4, 2020): 152-164; Zaenuri et al., "Habituation model of implementing environmental education in elementary school," Jurnal Pendidikan IPA Indonesia 6, no. 2 (Oktober 1, 2017): 206-212; Wahyudin dan Malik, "Teaching Environmental"

14 Septia Agustina, Irawan Suntoro, dan Yunisca Nurmalisa, "Peran Sekolah Islam Terpadu Dalam Pembentukan Karakter Religius Siswa Study kasus di SDIT Islam Terpadu Permata Bunda GedungMeneng Rajabasa Bandar Lampung TP 2012/2013," Jurnal Kultur Demokrasi 1, no. 2 (2012).

15 Subar dan Khuriyah Junanto, "Konsep pendidikan lingkungan hidup dalam perspektif islam," in Halaqoh Nasional dan Seminar Internasional Pendidikan (Surabaya: UIN Sunan Ampel, 2015), 121-135; Purwidianto, "Pendidikan Lingkungan Hidup dalam Perspektif Islam," Jurnal Pendidikan Islam 8, no. 2 (2017): 205-228; Dety Mulyanti, "Pendidikan Lingkungan Hidup Dalam Konsep Islam," Nizham 5, no. 2 (2016): 253-270.

16 Umi Musaropah, "Pendidikan Agama Islam Berwawasan Lingkungan Pada Anak Usia Dini (Studi Kasus di Pos PAUD Ananda Nologaten)," Ulumuddin: Jurnal Ilmu-ilmu Keislaman 4, no. 1 (2014): 48-57; Imroatun Imroatun, "Masjid dan Pengembangan Wawasan Anak Usia Dini dalam Pelestarian Lingkungan Hidup Nasional," Ulumuddin: Jurnal Ilmu-ilmu Keislaman 5, no. 1 (2015): 21-28. 
agar tertanam kesadaran terhadap hidup bersih dengan kepedulian pada pemeliharaan lingkungan dalam dan luar sekolah. ${ }^{17}$ Di tingkat selanjutnya, PLH bisa menjadi bagian dari pendidikan seumur hidup dalam kehidupan bermasyarakat. ${ }^{18}$

Dalam Suyatno,19 Sekolah itu dijelaskan sebagai salah satu model pendidikan Islam yang terintegrasi (terpadu) antara pendidikan agama dan pendidikan umum di mana semua mata pelajarannya adalah agama yang mengajarkan tauhid. Karena itu kurikulum dari Kementerian Pendidikan dan Kebudayaan bisa diterima secara total di situ sebanding dengan tawaran dari Kementerian Agama. SIT telah menjadi strategi Islamisasi terhadap semua komponen pendidikan, tujuan, kurikulum, strategi pendidikan, serta sumber belajar, termasuk guru, di lembaga pendidikan formal Indonesia. ${ }^{20}$

Penjabaran tentang kebijakan PLH yang ditawarkan dalam literatur PLH menjadi pokok bahasan dalam artikel ini. Tawaran literatur tentang kebijakan PLH itu tidak dijabarkan secara keseluruhan namun diseleksi guna mendapatkan strategi penting dalam implementasinya dalam pendidikan SIT. Dengan kekhasan yang ada di dalamnya, SIT tentu memerlukan model implementasi kebijakan yang tepat bagi PLH di lingkungannya.

\section{B. Metode Penelitian}

Kajian literasi atau literatur review merupakan bentuk uraian atau pendiskripsian tentang literatur relevan terhadap sebuah topik atau bahasan. Literatur tersebut memberikan gambaran atau pemahaman untuk peneliti atau penulis dalam mengkaji permasalahan kebijakan PLH di Sekolah Islam Terpadu. Dalam penelitian, PLH dikategorikan sebagai

17 Nia Hidayanti, Zainul Abidin, Arafah Husna, "Implementasi Pendidikan Lingkungan Hidup sebagai Kurikulum Muatan Lokal Ekopedagogi dalam Membangun Karakter Siswa di SDN Lowokwaru 2 Malang”, dalam Jurnal JINOTEP, Universitas Negeri Malang, Vol. 4, April, 2018, hlm. 107.

18 Fattah Setiawan Santoso, Diflah Nadjih, dan Imam Samroni, Penguatan Budaya Ramah Lingkungan Berbasis Fikih Di Kampung Nelayan Wilayah Poncosari Srandakan Bantul-DIY, Laporan Akademik Program Bantuan Peningkatan Mutu Pengabdian Kepada Masyarakat (Jakarta, 2015).

19 Suyatno Suyatno, "Sekolah Islam Terpadu Dalam Sistem Pendidikan Nasional," Al-Qalam 21, no. 1 (Januari 9, 2016): 1.

20 Ibid. 
kebijakan publik yang bisa menggunakan tiga pendekatan yang masingmasing telah ditawarkan oleh Edwards III, Meter dan Horn serta Grindle. ${ }^{21}$ Deksripsi ketiganya kemudian dianalisis muatannya guna mendapatkan relevansi dalam implementasi PLH di SIT yang menjadi bahasan.

\section{Deskripsi Hasil}

George C. Edwars III melihat implementasi kebijakan sebagai suatu proses bersifat dinamis di mana terdapat ragam faktor yang mempengaruhi implementasinya. Namun ia menyebut communication, resources, disposition, dan bureaucratic structure sebagai faktor penting. ${ }^{22}$

\section{Gambar 1}

\section{Model Implementasi Kebijakan menurut Edward III'3}

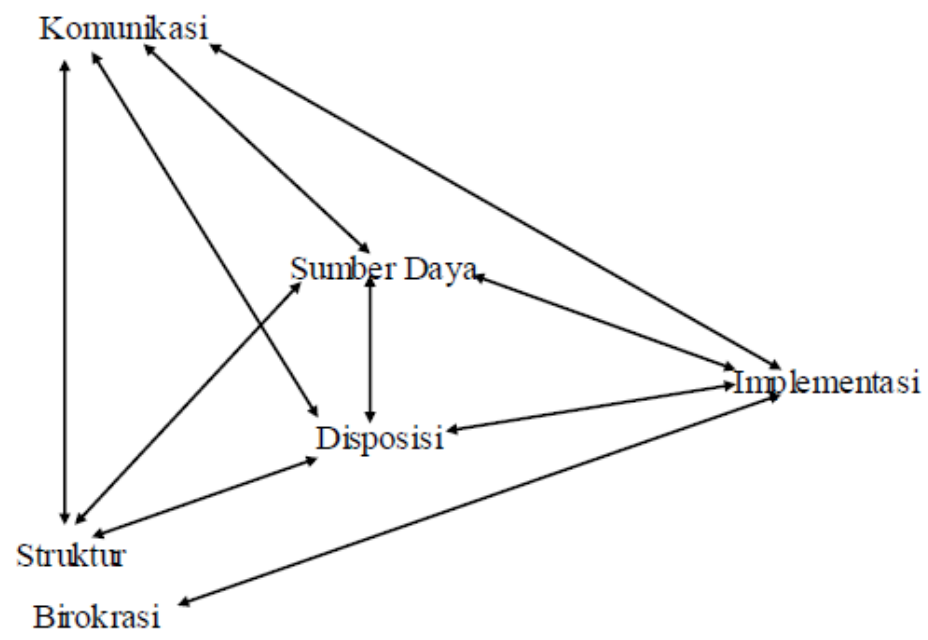

Komunikasi adalah penyampaian informasi dari komunikator kepada komunikan. Adapun komunikasi kebijakan berkenaan dengan penyampaian informasi kebijakan dari pembuat kebijakan (policy makers) kepada pelaksana (policy implementator). Di situ ada; transformasi

${ }^{21}$ Sudarwati, "Implementasi kebijakan."

22 Widodo, Analisis Kebijakan Publik: Konsep dan Aplikasi Analisis Proses Kebijakan Publik (Malang: Mayu Media, 2011),h.96-110. ${ }_{23}$ Sudarwati, "Implementasi kebijakan" 
informasi (transmision). kejelasan informasi (clarity), ketiga, konsisten informasi (consistency). ${ }^{24}$

Edwards III kemudidan menjelaskan faktor sumber daya yang efektif mendorong kepada keberhasilan.

"Bagaimanapun jelas dan konsistennya ketentuan-ketentuan dan aturan-aturan serta bagaimanapun akuratnya penyampaian ketentuan-ketentuan atau aturan-aturan tersebut, jika para pelaksana kebijakan yang bertanggung jawab untuk melaksanakan kebijakan kurang mempunyai sumber daya untuk melaksanakan kebijakan secara efektif, maka implementasi kebijakan tersebut tidak akan efektif." ${ }^{25}$

Penjabaran sumber daya berkaitan dengan segala upaya pendukung keberhasilan implementasi kebijakan. Sumber daya ini mencakup sumber daya manusia, anggaran, fasilitas, informasi, dan kewenangan. Sumber Daya Manusia (SDM) terdiri kuantitas dan kualitas. Kuantitas berkaitan dengan ketercukupan SDM pelaksana, sedang yang kedua berkaitan dengan profesionalitas, dedikasi, ketrampilan, dan kompetensi dalam menjalankan tugas sesuai bidang. Kedua, Anggaran berurusan dengan ketercukupan modal atau investasi lembaga dalam mengimplementasikan kebijakan. Ketiga, fasilitas atau sarana dan prasarana mendukung ketercapaian implementasi. Keempat, Informasi dan Kewenangan. Informasi yang baik, lugas dan relevan mempermudah keterlaksanaan kebijakan karena penerimanya cepat bertindak dengan pemahaman yang baik. Sementara kewenangan berperan penting untuk jaminan dan keyakinan terhadap anggota pelaksana kebijakan dan kolompok sasaran.

Model implementasi kebijakan yang kedua adalah menurut Van Meter dan Van Horn yang menambah spesifikasi lingkungan ekonomi, sosial, dan politik pada pendekatan Edward III. Terdapat lima variabel yang mempengaruhi kinerja implementasi, yaitu: Pertama, standar dan sasaran kebijakan. Kedua, sumber daya. Ketiga, komunikasi antar organisasi dan penguatan aktivitas. Keempat, karakteristik agen

24 Widodo, Analisis Kebijakan Publik: Konsep dan Aplikasi Analisis Proses Kebijakan Publik.

25 Ibid. 
pelaksana. Kelima, lingkungan ekonomi, sosial, dan politik. Keenam, sikap para pelaksana.

Gambar 2

Model Implementasi Kebijakan menurut Meter dan Horn²6

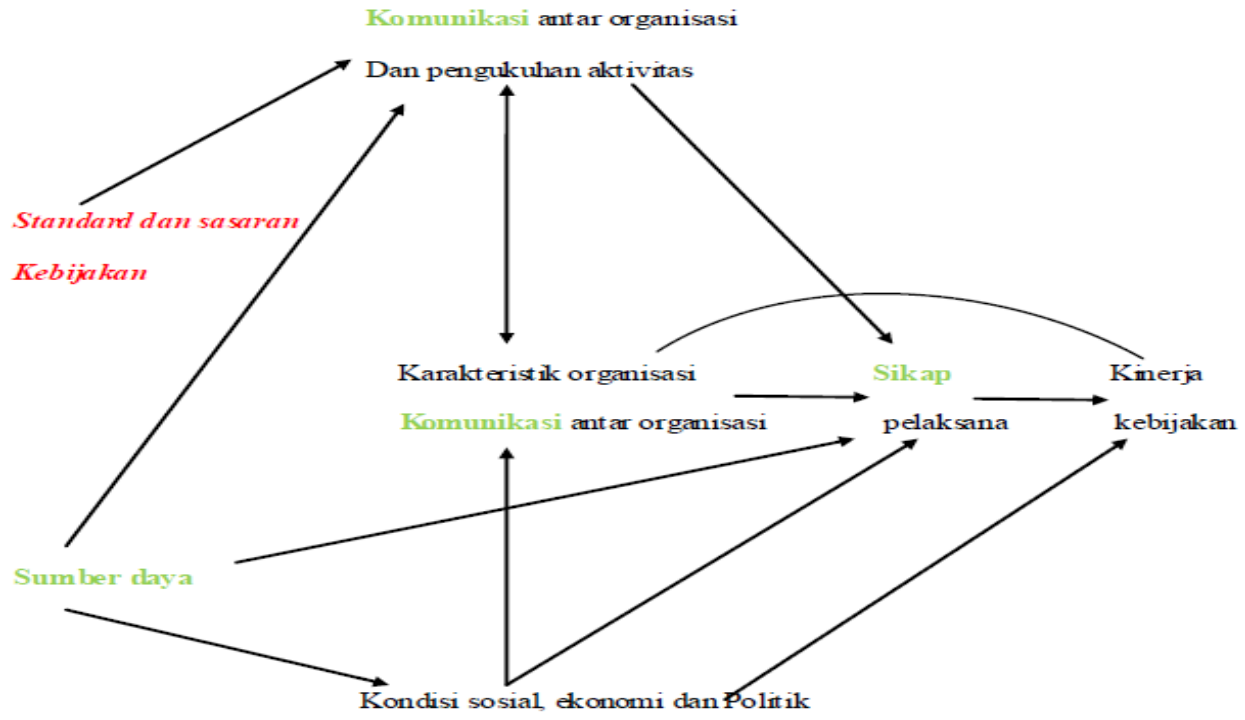

Grindle mengajukan model ketiga. ${ }^{27}$ Kebijakan publik setidaknya memuat; kepentingan yang dipengaruhi oleh kebijakan. jenis manfaat yang akan dihasilkan dan derajat perubahan yang diinginkan serta kedudukan pembuat kebijakan dengan melihat siapa pelaksana program dan sumber daya yang dikehendaki. Ia menegaskan bahwa kebijakan yang bertempo panjang akan lebih sukar untuk diimplementasikan karena fenomena lingkungan kebijakan mempengaruhi prosesnya, baik ekonomi, politik, maupun sosial seperti yang dikemukakan oleh Meter dan Horn. Kondisi itu meliputi (1) kekuasaan, kepentingan, dan strategi yang dimiliki oleh para aktor yang terlihat dalam implementasi kebijakan, (2) karakteristik lembaga dan penguasa, dan (3) kepatuhan dan daya tanggap atau responsibilitas kelompok sasaran.

26 Sudarwati, "Implementasi kebijakan"; Subarsono AG, Analisis Kebijakan Publik (Yogyakarta: Pustaka Pelajar, 2006). h??

${ }_{27}$ AG, Analisis Kebijakan Publik. 


\section{Gambar 3 \\ Implementasi Kebijakan menurut Grindle ${ }^{28}$}

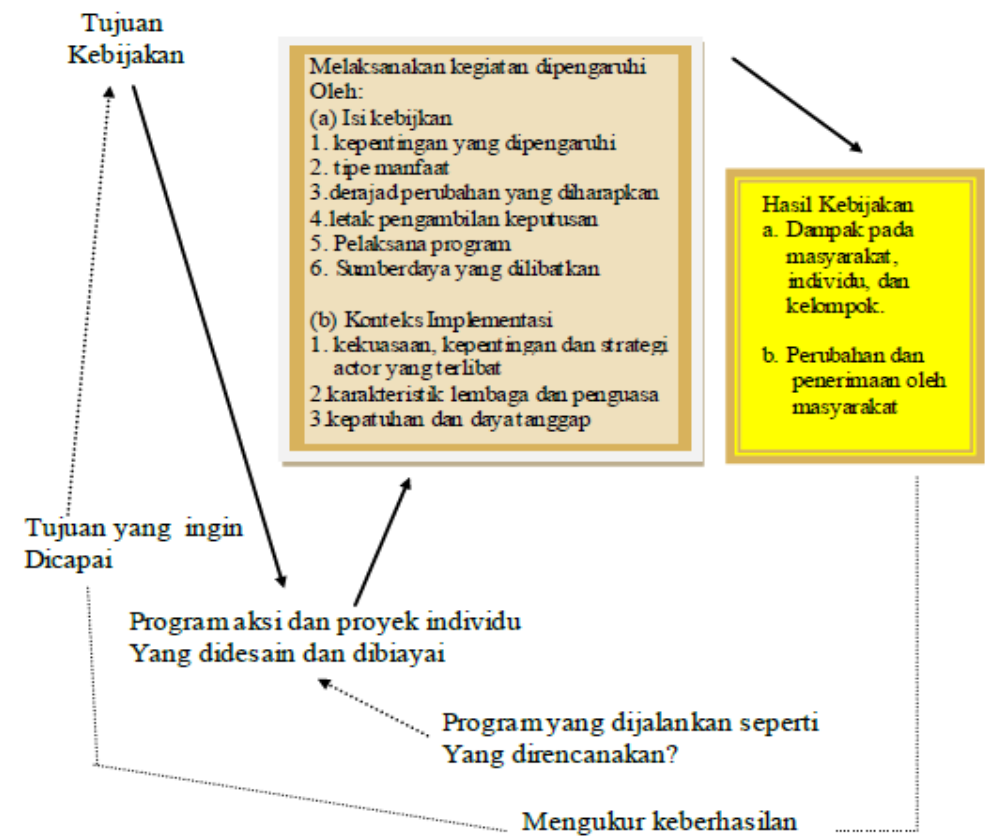

\section{Strategi Implementasi kebijakan PLH di Sekolah Islam Terpadu}

Ragam model kebijakan implementasi PLH di sekolah telah memberikan beberapa kemungkinan dalam penerapannya di SIT. Pemilihan salah satu atau kombinasi dari ketiga pendekatan implementasi kebijakan itu masih perlu disesuaikan dengan konteks kelembagaan yang memiliki visi misi khas seperti SIT. Di situ dibutuhkan pengembangan karakter, baik secara makro maupun mikro. Bagi Sulistyowati, implementasi kebijakan dalam sekolah memerlukan proses pembudayaan dan pemberdayaan. ${ }^{29}$

Karakter Islam adalah ciri penting dalam SIT, didalamnya ada pengutamaan terhadap pendidikan karakter Islam telah menjadi pegangan penting dalam pendidikan Islam. Karenanya, Suyatno menyatakan keterpaduan dalam tujuan SIT tidak membedakan antara ilmu agama dan umum untuk menghindari pembentukan karakter jiwa yang terlanda dengan split personality dengan meneladani praktek pendidikan Nabi

${ }^{28}$ Ibid.; Sudarwati, "Implementasi kebijakan"

29 Sulistyowati Endah, Implementasi Kurikulum Pendidikan Karakter, (Yogyakarta: Citra Aji Parama, 2012). 
Muhammad saw.30 Dalam nada yang sama, Kurnaengsih menjabarkan lebih lanjut. ${ }^{31}$ Beberapa di antaranya telah mengadaptasi sistem boarding school yang berorientasi pada inkulturasi kedisiplinan dan kesalehan beragama pada siswa. Meski demikian didalamnya ada keyakinan bahwa pemaduan sains dan Islam adalah keniscayaan seiring dengan peningkatan kesadaran umat untuk mengimplementasikan iman dalam berbagai bidang kehidupan duniawi. SIT telah mengembangkan sistem pendidikan melalui pendidikan berkehidupan yang sesuai dengan masa awal kebangkitan Islam.

Kebijakan PLH di pendidikan SIT perlu disertai dengan pembudayaan dan pemberdayaan. Sulistyowati menunjukkan dua pilihan langkah yang memungkinkan untuk dilakukan yakni langsung mengimplementasikan dalam bentuk program-program, atau dapat melalui kebijakan turunan, yaitu melalui tahapan-tahapan, baik melalui intervensi maupun habituasi.

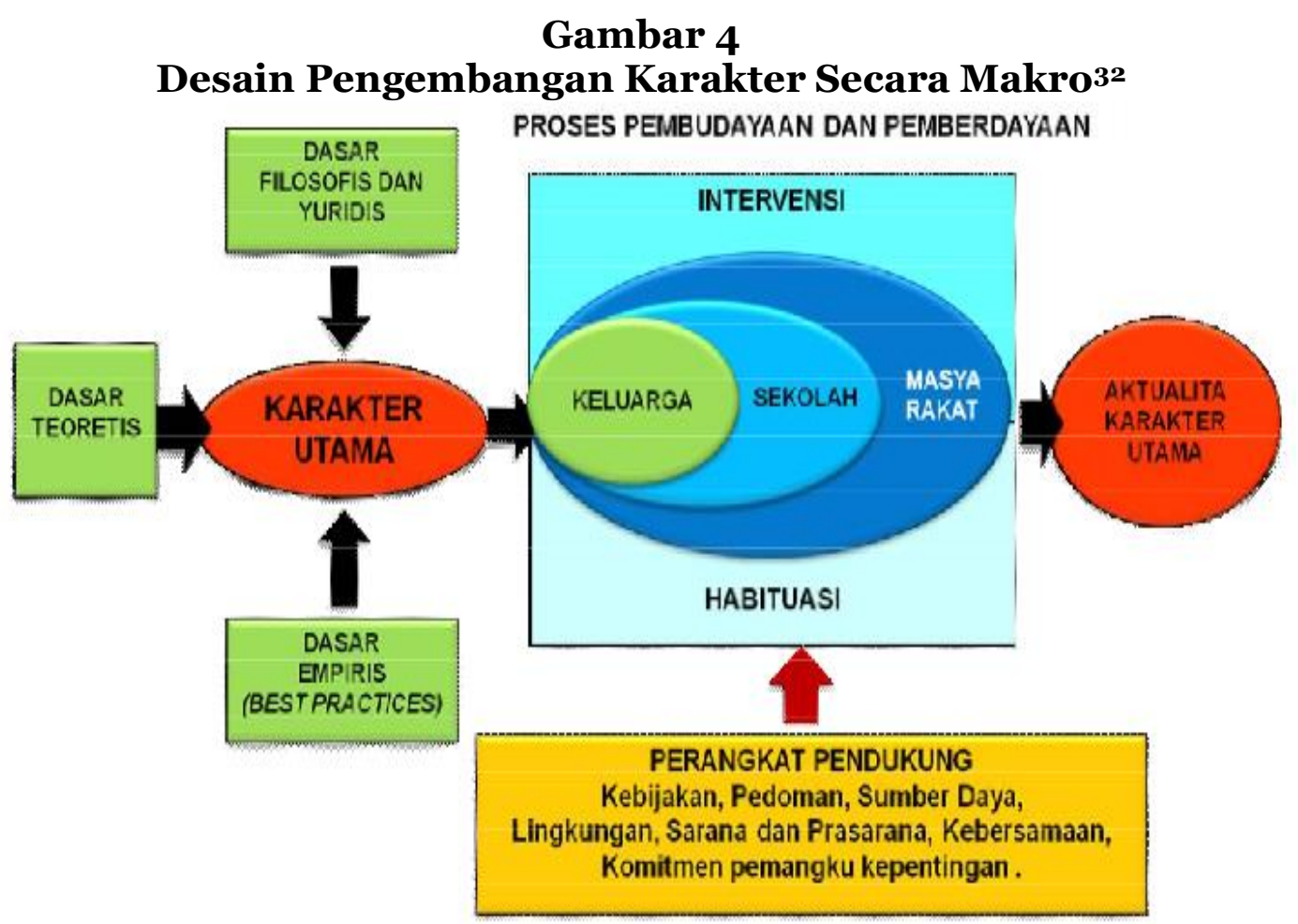

$3^{\circ}$ Suyatno, "Sekolah Islam."

${ }^{31}$ Kurnaengsih, "Konsep sekolah islam terpadu Kajian Pengembangan Lembaga Pendidikan Islam di Indonesia," Risalah Pendidikan dan Studi Islam 1, no. 1 (2015): $78-$ 84.

${ }^{2}$ Endah, Implementasi Kurikulum, 
Dalam struktur alur di atas implementasi PLH dilaksanakan berkaitan dengan lingkungannya. Semua itu berjalan melalui proses pemberdayaan dan pembudayaan yang dilakukan oleh semua lingkungan pendidikan. Lingkungan sekolah, keluarga, dan masyarakat melalui intervensi dan habituasi.33

Dalam ranah intervensi diperlukan pengkondisian yang terencana untuk mencapai tujuan pendidikan lingkungan hidup yang diharapkan. Guru menjadi panutan bagi siswa dan penentu ketercapaian tujuan, sementara keluarga dan masyarakat memberikan kontribusi pembelajaran melalui perilaku karakter yang baik.34 Di ranah habituasi, situasi dan kondisi diciptakan yang memungkinkan siswa selama di sekolah, rumah, dan masyarakat terbiasa dalam perbuatan setara dengan karakter yang terinternalisasi pada tahapan intervensi.

\section{Gambar 5} Proses Pembudayaan dan Pemberdayaan 35

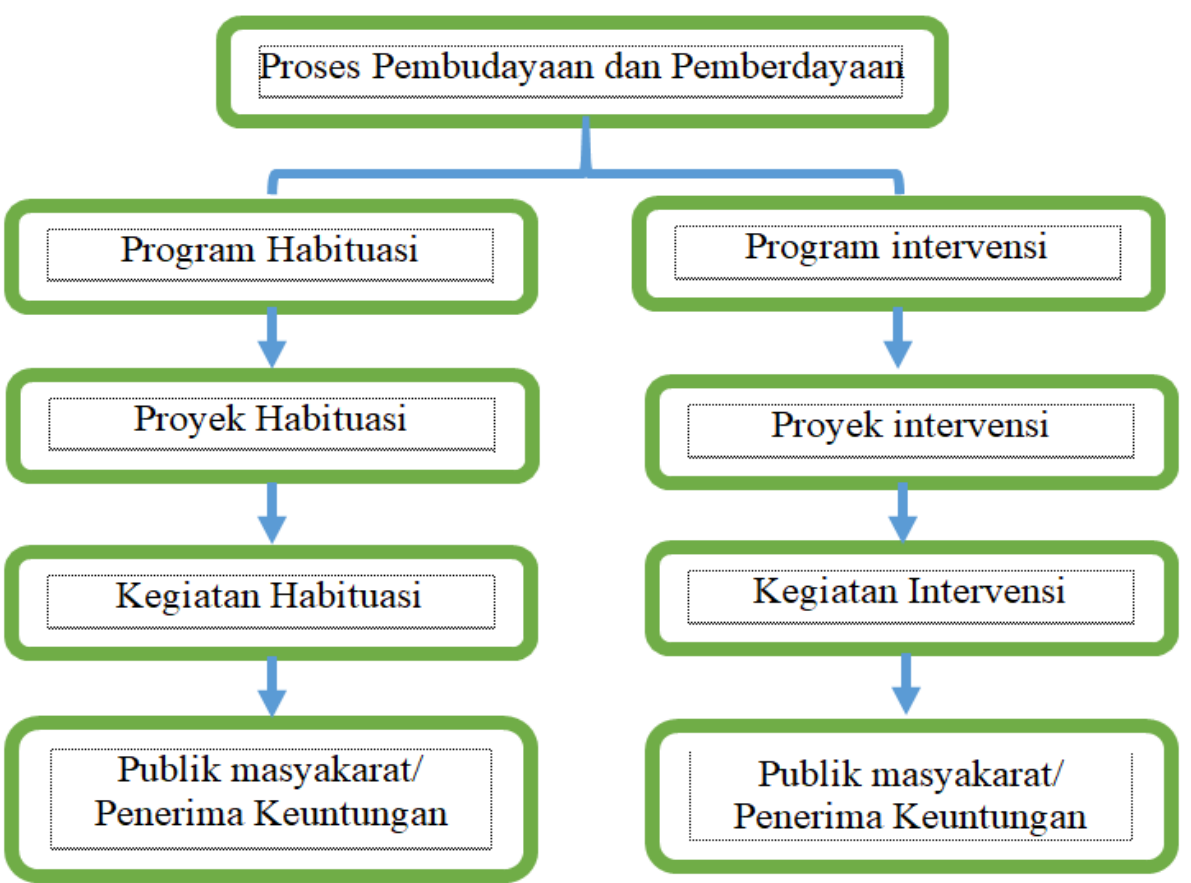

33 Ibid.

34 Ibid.

35 Ibid. 
Proses pembudayaan dan pemberdayaan kemudian telah mencakup pemberian contoh, pembelajaran, pembiasaan, dan penguatan yang harus dikembangkan secara sistemik, holistik, dinamis, kuat, dan berpikiran argumentatif. Harapan besar terjadinya keselarasan antara satu dengan lingkungan pendidikan lain, yaitu; sekolah, keluarga, dan masyarakat sehingga terjadi proses pembudayaan sekaligus pemberdayaan karakter secara efektif. ${ }^{36}$

Sekolah menjadi pendidikan karakter mikro. Fungsinya jelas dalam pencegahan dari degradasi mental dan moral secara efektif. Sekaligus di dalamnya sekolah menjadi tempat yang optimal terproses dari inisiasi, perbaikan, penguatan, hingga penyempurnaan kualitas secara terus menerus melalui pendidikan karakter.37 Polarisasi pendidikan karakter mikro di sekolah dibagi kedalam empat pilar, yakni belajar mengajar di kelas, keseharian dalam bentuk pengembangan budaya sekolah, kokurikuler, dan ekstrakurikuler, serta keseharian dirumah dan masyarakat. 38

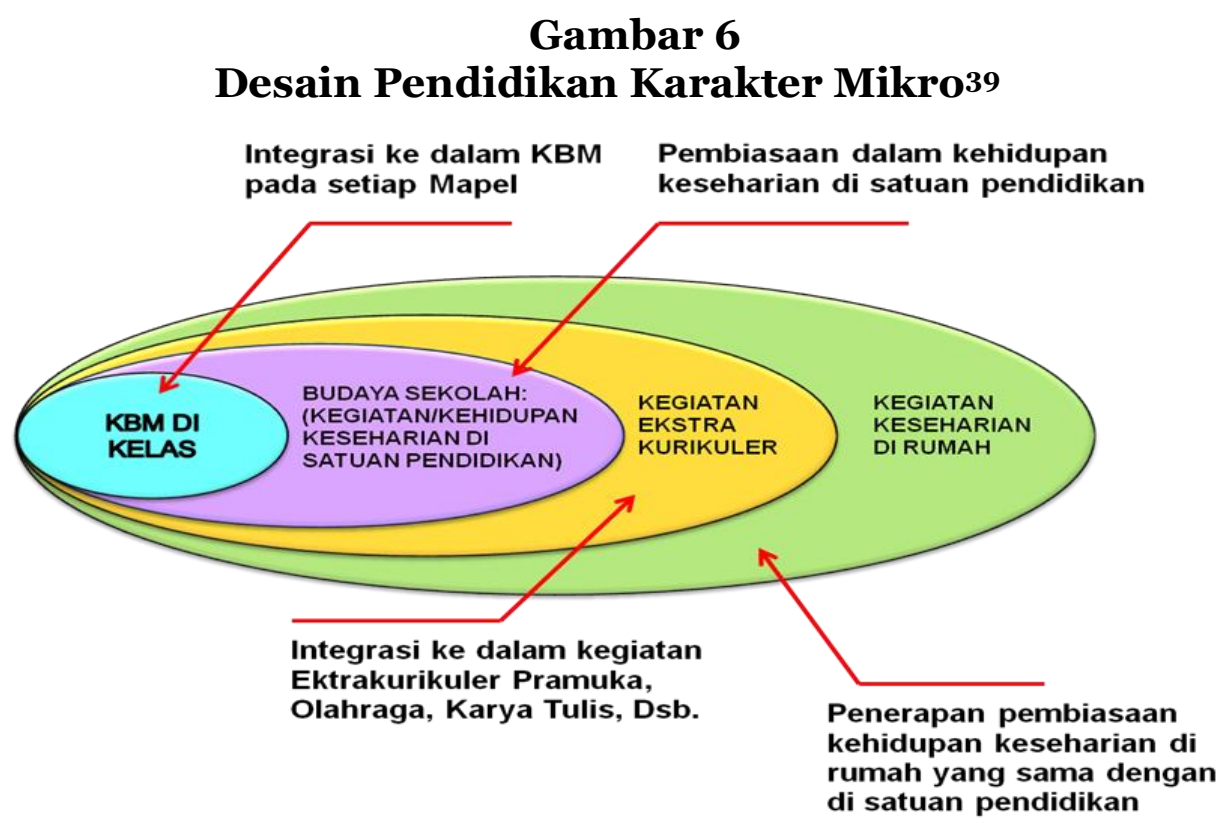

Menurut Abidin ${ }^{40}$, pelaksanaan kebijakan secara umum akan mengalami hambatan dari sekedar merumuskan. Hambatan tersebut

$$
\begin{aligned}
& { }^{6} \text { Ibid. } \\
& 37 \text { Ibid. } \\
& 38 \text { Ibid. } \\
& 39 \text { Ibid. }
\end{aligned}
$$


terjadi karena proses perumusan kebijakan memerlukan pemahaman tentang berbagai aspek. Menjadikan tidak semua kebijakan dapat dilaksanakan dengan sempurna. "Pelaksanaan menyangkut kondisi riil yang sering berubah dan sukar diprediksi." Selain itu terjadinya hambatan kebijakan dalam pelaksanaan terjadi karena dalam proses perumusan terdapat asumsi, generalisasi, dan simplikasi yang dalam penerapannya sulit untuk direalisasikan sehingga muncul implementation gap atau kesenjangan antara rencana dengan proses pelaksanaan. Meskipun praktik kesenjangan itu dapat ditoleransi namun tetap dibutuhkan evaluasi agar tim pelaksana dapat memperbaiki kekurangan.

\section{E. Penutup}

Tiga model Kebijakan publik bagi PLH yang diuraikan telah memberikan wawasan bagaimana PLH harus diterapkan dalam SIT. Strategi kombinasinya dengan pembudayaan dan pembiasaan diharapkan memberikan dampak kuat terhadap karakter semua pihak yang terlibat dalam pendidikan terpada SIT. Prinsip demokrasi dalam pendidikan bisa mendorong partisipasi aktif semua pihak dalam sekolah termasuk dalam penuyusunan kebijakan sekolah yang disertai dengan pengaturan distribusi yang menekankan kebebasan bertanggung jawab dalam pelaksanaannya menjadikan PLH di SIT bisa berjalan dalam jalur keislaman yang mendukung pemantapan kesadaran lingkungan berkelanjutan dalam program Adiwiyata. Demokrasi juga menjamin kesinambungan pelaksanaan kebijakan yang tidak memberatkan pihak sasaran atau pelaksanaan kebijakan.

\section{Daftar Pustaka}

AG, Subarsono. Analisis Kebijakan Publik. Yogyakarta: Pustaka Pelajar, 2006.

Agustina, Septia, Irawan Suntoro, dan Yunisca Nurmalisa. "Peran Sekolah Islam Terpadu Dalam Pembentukan Karakter Religius Siswa Study kasus di SDIT Islam Terpadu Permata Bunda GedungMeneng Rajabasa Bandar Lampung TP 2012/2013.” Jurnal Kultur Demokrasi 1, no. 2 (2012).

Azmi, Fadila, dan Elfayetti Elfayetti. "Analisis Sikap Peduli Lingkungan Siswa Melalui Program Adiwiyata Di SMA Negeri 1 Medan.” Jurnal

40 Said Abidin Zainal, Kebijakan Publik (Jakarta: Yayasan Pancur Siwah, 2004). 
Geografi 9, no. 2 (Agustus 8, 2017): 135.

Bahrudin, Mohammad Dendy Fathurahman. "Pelaksanaan Program Adiwiyata Dalam Mendukung Pembentukan Karakter Peduli Lingkungan." Gea. Jurnal Pendidikan Geografi 17, no. 1 (2017): 2537 .

Braja, Das. "Pendidikan Lingkungan Hidup Sebagai Muatan Lokal Pada Sekolah Adiwiyata di SDN Purwantoro I Kota Malang," n.d.

Donna, Erika, Meissy Karmanto, Moch Makmur, dan Ainul Hayat. "Kebijakan Pengintegrasian Pendidikan Lingkungan Hidup Pada Sekolah Adiwiyata (Studi pada Sman 1 Puncu Kecamatan Puncu Kabupaten Kediri)." Jurnal Administrasi Publik (JAP) 3, no. 12 (2015): 1981-1985.

Endah, Sulistyowati. Implementasi Kurikulum Pendidikan Karakter,. Yogyakarta: Citra Aji Parama, 2012.

Imroatun, Imroatun. "Masjid dan Pengembangan Wawasan Aak Usia Dini dalam Pelestarian Lingkungan Hidup Nasional." Ulumuddin: Jurnal Ilmu-ilmu Keislaman 5, no. 1 (2015): 21-28.

Junanto, Subar dan Khuriyah. "Konsep pendidikan lingkungan hidup dalam perspektif islam." In Halaqoh Nasional dan Seminar Internasional Pendidikan, 121-135. Surabaya: UIN Sunan Ampel, 2015 .

Kadorodasih. "Implementasi Pendidikan Lingkungan Hidup Melalui Program Adiwiyata Di SDN Giwangan Yogyakarta." Hanata Widya 6, no. 4 (2017): 43-53.

Ketut, Prasetyo, dan Hariyanto. Pendidikan Lingkungan Indonesia. Bandung: Rosdakarya, 2017.

Kurnaengsih. "Konsep sekolah islam terpadu Kajian Pengembangan Lembaga Pendidikan Islam di Indonesia." Risalah Pendidikan dan Studi Islam 1, no. 1 (2015): 78-84.

Mulyanti, Dety. "Pendidikan Lingkungan Hidup Dalam Konsep Islam." Nizham 5, no. 2 (2016): 253-270.

Musaropah, Umi. "Pendidikan Agama Islam Berwawasan Lingkungan Pada Anak Usia Dini (Studi Kasus di Pos PAUD Ananda Nologaten)." Ulumuddin: Jurnal Ilmu-ilmu Keislaman 4, no. 1 (2014): 48-57.

Nadjih, Difla, Sujarwo Saputro, dan Mukhlas Madani. "Identifikasi Jumlah dan Faktor Timbulan Sampah Di Kawasan Wisata Malioboro ." Nuansa Akademik Jurnal Pembangunan Masyarakat 5, no. 1 (Mei 14, 2020): 35-43.

Nihlawati, Siti. "Substansi Kebijakan Kurikulum Berbasis Lingkungan pada Sekolah Adiwiyata di SMPN 2 Kebomas Gresik.” Didaktika 18, no. 2 (2011): 6-21.

Nofijantie, Lilik. "Menanamkan Nilai Karakter Peduli Lingkungan Melalui Pendidikan Lingkungan Hidup Tantangan Bagi FITK.” In Prosiding Halaqah Nasional dan Seminar Internasional Pendidikan Islam., 83-91. Surabaya: UIN Sunan Ampel, 2015.

Purwidianto. "Pendidikan Lingkungan Hidup dalam Perspektif Islam." Jurnal Pendidikan Islam 8, no. 2 (2017): 205-228.

Rahman, Ayu Awalia, I Made Putrawan, dan Mieke Miarsyah. "Hubungan 
Antara Orientasi Nilai (Value Orientation) dengan Perilaku Pro Lingkungan (Pro Environmental Behavior) Siswa." IJEEM Indonesian Journal of Environmental Education and Management 5, no. 2 (Maret 4, 2020): 152-164.

Rahmawati, Arum Yuli Dwi, Muh Nasruddin, dan Imroatun Imroatun. "Peran Sosial Guru Pendidikan Agama Islam Di Wilayah Pesisir Utara Pulau Jawa." Nuansa Akademik Jurnal Pembangunan Masyarakat 5, no. 1 (2020): 1-12.

Republik Indonesia. Undang-undang Nomor 32 tahun 2009 tentang Perlindungan dan Pengelolaan Lingkungan Hidup, 2009.

Santoso, Fattah Setiawan. "Lingkungan Keluarga Sebagai Awal Pengembangan Kewirausahaan Islam.” Nuansa Akademik Jurnal Pembangunan Masyarakat 5, no. 1 (2020): 13-22.

Santoso, Fattah Setiawan, Diflah Nadjih, dan Imam Samroni. Penguatan Budaya Ramah Lingkungan Berbasis Fikih Di Kampung Nelayan Wilayah Poncosari Srandakan Bantul-DIY, Laporan Akademik Program Bantuan Peningkatan Mutu Pengabdian Kepada Masyarakat. Jakarta, 2015.

Sudarwati, Theresia Melania. "Implementasi kebijakan pendidikan lingkungan hidup SMAN 11 Semarang menuju Sekolah Adiwiyata.” Universitas Diponegoro Semarang, 2012.

Sungkowo. Konsep Pendidikan Lingkungan Hidup pada Jalur Pendidikan Dasar dan Menengah. Jakarta: Dikdasmen, 2005.

Suyatno, Suyatno. "Sekolah Islam Terpadu Dalam Sistem Pendidikan Nasional." Al-Qalam 21, no. 1 (Januari 9, 2016): 1.

Syukri, Hamzah. Pendidikan Lingkungan, Sekelumit Wawasan Pengantar. Bandung: Refika Tama, 2015.

Umam, Khoirul. "PLH di SDN Malang." UIN MMI Malang, 2018.

Wahyudin, Dinn, dan Ranbir Singh Malik. "Teaching Environmental Education For Sustainable Development: Strategies And Challenges." Journal of Sustainable Development Education and Research 3, no. 1 (Mei 14, 2019): 51-70.

Widodo. Analisis Kebijakan Publik: Konsep dan Aplikasi Analisis Proses Kebijakan Publik. Malang: Mayu Media, 2011.

Zaenuri, Sudarmin, Y. Utomo, dan E. Juul. "Habituation model of implementing environmental education in elementary school." Jurnal Pendidikan IPA Indonesia 6, no. 2 (Oktober 1, 2017): 206212.

Zainal, Said Abidin. Kebijakan Publik. Jakarta: Yayasan Pancur Siwah, 2004. 